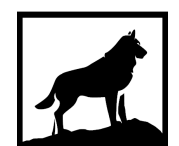

Michigan Technological

1 в 8 5 University
Michigan Technological University Digital Commons @ Michigan Tech

\title{
COMPARISON OF KARSTIFICATION METHODS AND ISOSTATIC REBOUND IN THE SUWANNEE RIVER BASIN, FLORIDA
}

Toni Larche

Michigan Technological University, tllarche@mtu.edu

Copyright 2018 Toni Larche

Recommended Citation

Larche, Toni, "COMPARISON OF KARSTIFICATION METHODS AND ISOSTATIC REBOUND IN THE SUWANNEE RIVER BASIN, FLORIDA", Open Access Master's Thesis, Michigan Technological University, 2018.

https://doi.org/10.37099/mtu.dc.etdr/599

Follow this and additional works at: https://digitalcommons.mtu.edu/etdr

Part of the Geomorphology Commons 


\title{
COMPARISON OF KARSTIFICATION METHODS AND ISOSTATIC REBOUND IN THE SUWANNEE RIVER BASIN, FLORIDA
}

\section{By}

Toni L. Larche

\author{
A THESIS \\ Submitted in partial fulfillment of the requirements for the degree of \\ MASTER OF SCIENCE \\ In Geology \\ MICHIGAN TECHNOLOGICAL UNIVERSITY \\ 2018
}

(C) 2018 Toni L. Larche 
This thesis has been approved in partial fulfillment of the requirements for the Degree of MASTER OF SCIENCE in Geology.

Department of Geological \&Mining Engineering \& Sciences

\author{
Thesis Co-Advisor: Dr. Jason Gulley \\ Thesis Co-Advisor: Dr. John Gierke \\ Committee Member: Dr. Melanie Kueber Watkins \\ Department Chair: $\quad$ Dr. John Gierke
}


Dedicated to my son, Tate Socko. 


\section{Table of Contents}

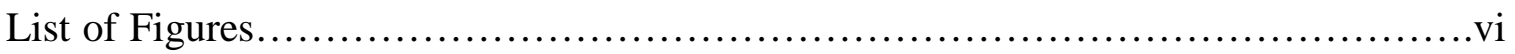

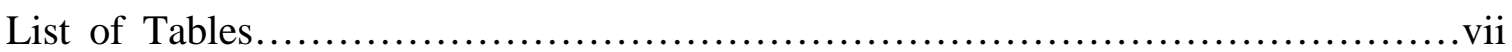

Acknowledgements ......................................................................

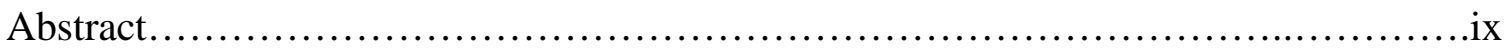

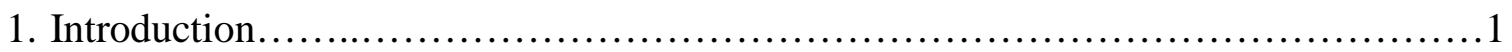

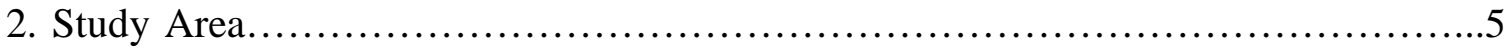

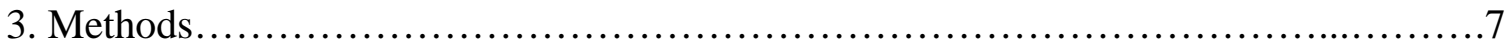

3.1 Water Flux from the Suwannee River Basin................................ 7

3.2 $\mathrm{Ca}^{2+}$ Flux from the Suwannee River Basin.....................................

3.3 $\mathrm{Ca}^{2+}$ Flux from the Concentration-Discharge Relationship....................8

3.4 $\mathrm{Ca}^{2+}$ Flux from the Concentration-Conductivity Relationship.................9

3.5 Chemostatic $\mathrm{Ca}^{2+}$ Flux............................................... 10

3.6 Karstification...........................................................

3.7 Uplift................................................................

3.8 Rainfall and Evapotranspiration.......................................12

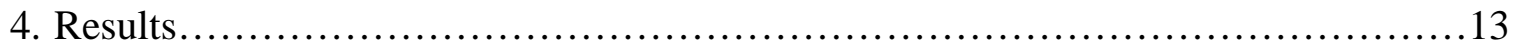

4.1 Rainfall and Evapotranspiration.........................................13

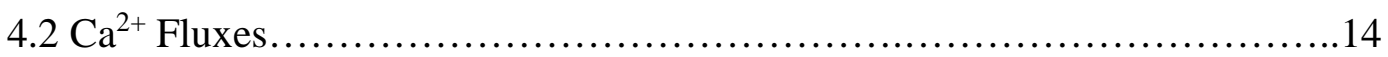

4.3 Karstification............................................................ 19

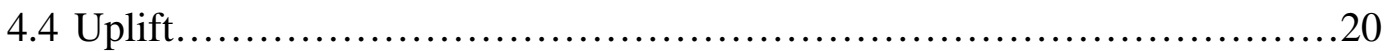

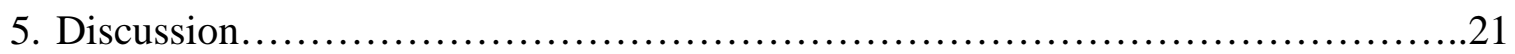

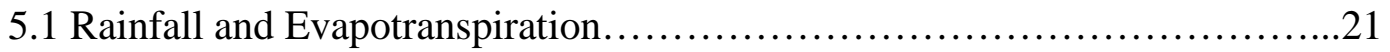

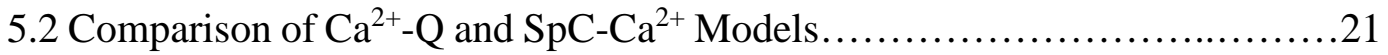

5.3 Chemostatic Model....................................................22

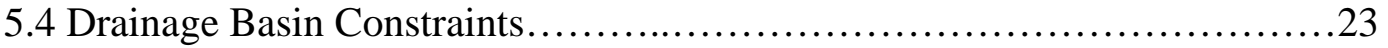

5.5 Comparison of Opdyke, Willet, and Adams Studies.........................23

5.6 Comparison of Uplift Calculations.......................................25 
5.7 Unresolved Questions .

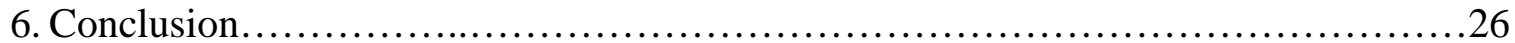

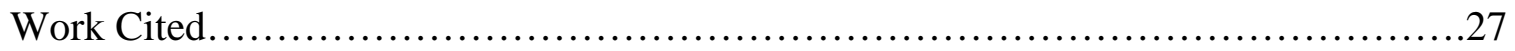




\section{List of Figures}

Figure 1. Methods of Isostatic Response.........................................2

Figure 2. Map of the Suwannee River Basin.....................................5

Figure 3. Ratings Curve of $\mathrm{Ca}^{2+}$ compared to Discharge...............................9

Figure 4. Ratings Curve of $\mathrm{Ca}^{2+}$ compared to Specific Conductance.....................10

Figure 5. Yearly Comparison of Discharge, Rainfall, and Evapotranspiration..............12

Figure 6. $\mathrm{Ca}^{2+}-\mathrm{Q}$ Data

A) Residual Data........................................................16

B) Time Series of $\mathrm{Ca}^{2+}$ Flux verse Geochemical Measurements...................16

Figure 7. SpC - $\mathrm{Ca}^{2+}$ Data

A) Residual Data...................................................... 18

B) Time Series of $\mathrm{Ca}^{2+}$ Flux verse Geochemical Measurements...................18

Figure 8. $\mathrm{Ca}^{2+}-\mathrm{Q}$ Flux using Chemostatic method................................ 19

Figure 9. Comparison of Karstification Rates......................................20 


\section{List of Tables}

Table 1. Average Karstification Rates Determined from Previous Studies................4

Table 2. Annual loss of $\mathrm{Ca}^{2+}$ from Suwannee River Basin..............................15 


\section{Acknowledgements}

Thank you, Dr. Jason Gulley for your support, guidance, and patience. Thank you to James, Chuck, and Charlie for all the encouragement and technical assistance. 


\section{Abstract}

Plio-Pleistocene beach ridges in northern Florida are nearly 50 m above current sea level, but sea level during that time is not known to have been more than $25 \mathrm{~m}$ above current sea level. The height of beach ridges in northern Florida therefore create a conundrum because Florida is located on a passive margin in what is considered a tectonically stable environment. A series of recent studies have suggested that uplift on the Florida peninsula may be the result of the removal of subsurface crustal mass. Karstification of Florida’s carbonate matrix may provide a mechanism for subsurface crustal mass removal and regional isostatic uplift. The ability of karstification to drive uplift was assessed using a calcium mass balance study of the Suwannee River Basin, in north Central Florida. Limestone dissolution in the entire basin was determined though statistical relationships between $\mathrm{Ca}^{2+}$, which is the dominant cation in surface and groundwater and a primary component of calcite, and SpC and discharge. Because some water discharging from the Suwannee River Basin is also undersaturated with respect to calcite, maximum karstification potential for the basin was also calculated by assuming chemostatic conditions. Similar to past studies, isostatic uplift was calculated by assuming all dissolution occurred in the subsurface. Results from the application predicted anywhere from 77 to $6.7 \mathrm{~mm} \mathrm{k.y.}{ }^{-1}$ of uplift, with three of the six methods between 24 to 29 mm k.y. ${ }^{-1}$. Based on the results, karstification may be able to partially explain isostatic uplift of the northern Florida peninsula. 


\section{Introduction}

Plio-Pleistocene beach terraces in Florida reach elevations of nearly $50 \mathrm{~m}$ above sea level (masl) (Pirkle and Czel, 1983). The origin of these beach ridges has remained problematic because sea level only reached $25 \mathrm{~m}$ during the Plio-Pliestocene, indicating that the beach ridges could not have formed 50 masl (Miller et al., 2005), and Florida's position on a passive margin means tectonic uplift of beaches that formed at lower elevations is unlikely. Previous work has consequently suggested that beach terraces in Florida could have possibly reached their present elevations via karstification of carbonate bedrock and isostatic uplift (Opdyke et al., 1984; Willet, 2006; Adams et al., 2010).

Isostatic rebound can be induced by any process that removes mass from the Earth's surface, because the crust “floats” on the mantle (Anderson and Anderson, 2010). Removal of crustal material causes the remaining crust to "float" higher in the asthenosphere. Isostatic rebound has typically been attributed to removal of crustal material by valley incision (Lucchitta, 1979), mountain erosion (Champagnac, 2007) or removal of ice through regional deglaciation (Farrand, 1962), (Figure 1). The dissolution of carbonate rock, otherwise known as karstification, also removes crustal mass, but much of the crustal mass is removed from the subsurface through processes of dissolution and cave formation. 


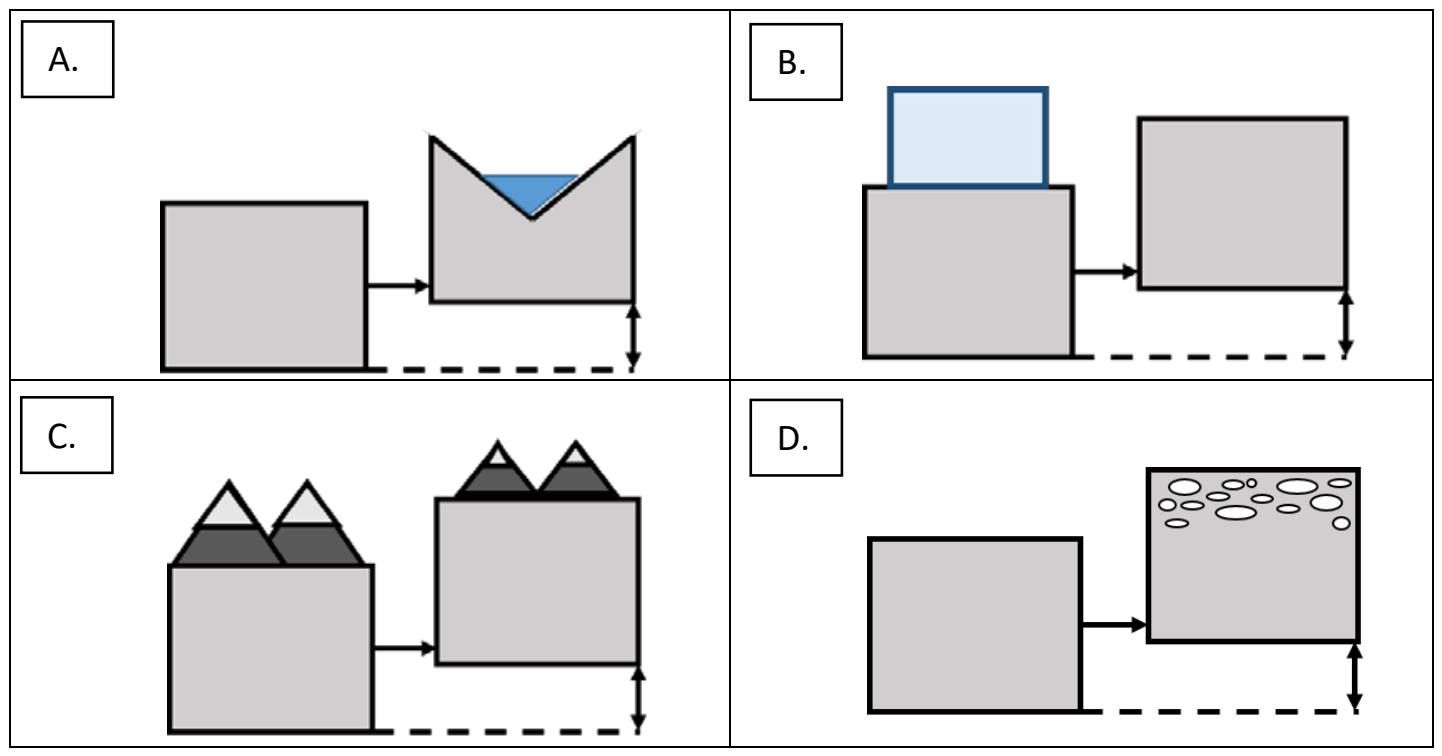

Figure 1: Methods of isostatic response by removal of crustal material. (A) Fluvial or glacial erosion incising the landscape and removing mass. (B) Regional deglaciation removes overlying mass from the crust. (C) Mountain erosion displacing sediment over a region (D) Karstification dissolves carbonate.

Isostatic rebound in not a one to one ration between karstification and uplift, but instead accounts for several variables acting on the asthenosphere. Assuming surface denudation is negligible, the decrease in crustal density caused by karstification should allow for isostatic uplift, as described by the following equation:

$$
U=\frac{(\check{\mathrm{K}})\left(\rho_{b i}\right)}{\rho_{b i}+\rho_{\text {eff }}}
$$

With $U$ being uplift of the crustal plates, $\check{K}$ yearly karstification of the crustal plate, $\rho_{b i}$ representing original density of the carbonate matrix (2200 $\left.\mathrm{kg} \mathrm{m}^{-3}\right)$, and $\rho_{\text {eff }}$ is the effective density of the thickness of the crustal plate, or the difference in mass between 
the uplifted limestone mtrix and that which remains below the original surface (200 kg $\mathrm{m}^{-3}$ ) (Opdyke et al., 1984).

Three studies have investigated the role of karstification in driving uplift of the Florida Plateau, each arriving at different karstification and uplift rates (Table 1). Opdyke et al. (1984) calculated karstification based on the mass flux of total dissolved solids from springs (e.g. Rosenau and Faulker (1975), Rosenau et al. (1977), and Slack and Rosenau (1979)). Willet (2006) also relied on mass flux data from springs, but used a dataset with a larger number of springs over a larger area than the Opdyke study (e.g. Rosenau et al., 1977; Scott et al., 2002; and Scott et al., 2004). In both the Opdyke and Willet studies, modern karstification rates were assumed to be representative of karstification rates from the Plio-Pleistocene until the modern. Realizing that karstification rates were likely to vary due to climate variability between the PlioPliestocene and the modern, Adams et al. (2010) created a numerical model that related karstification rates to rainfall:

$$
\breve{\mathrm{K}}=\lambda \dot{\mathrm{P}}
$$

where $\check{\mathrm{K}}$ is the average karstification rate, $\mathrm{P}$ is precipitation, and $\lambda$ is a dimensionless parameter used as a calibration (tuning) factor. The tuning parameter was used to describe the efficiency of dissolution in the carbonate matrix needed for karst-driven changes in crustal density to uplift beach ridges to their current elevations before being removed by surficial erosion (Adams et al., 2010). 
Table 1: Karstification and Uplift Rates of from previous studies:

Opdyke et al. (1984), Willet (2006), and Adams et al. (2010).

\begin{tabular}{|lccc|}
\hline & Opdyke & Willet & Adams \\
Karstification $\left(\mathrm{m} \mathrm{k.y.}^{-1}\right)$ & 0.0263 & 0.00733 & 0.0840 \\
Uplift $\left(\mathrm{m} \mathrm{k.y.}^{-1}\right)$ & 0.0241 & 0.00672 & 0.0770 \\
\hline
\end{tabular}

Large differences in karstification and uplift rates calculated in these studies stem from differences in research methods. Studies of mass flux from individual springs relied on point measurements rather than time series data; consequently, the Opdyke et al., (1984) and Willet (2006) studies do not consider how temporal variability in spring discharge could impact carbonate relationships, and hence flux of dissolved solids from springs. Similarly, the Adams et al. (2010) model relates karstification to rainfall, but since the karstification model was not calibrated against observed karstification rates, its ability to represent actual karstification rates remains untested. Of particular concern is that the model relates karstification to rainfall rather than recharge. Evapotranspiration results in significant quantities of rainfall leaving the Florida carbonate platform as water vapor which does not transport dissolved solids.

In this study, several combinations of legacy data from the Suwannee River Basin were used to better constrain karstification and uplift rates in the Florida carbonate platform. Statistical relationships between daily average discharge and specific conductivity (SpC) measurements and measurements of $\mathrm{Ca}^{2+}$ concentrations in water samples collected at approximately monthly intervals at a United States Geological Survey gaging station near the mouth of the Suwannee River were used to estimate 
karstification rates for the entire river basin. These results are compare to those of the Willet (2006), Opdyke et al. (1984), and Adams et al. (2010) studies.

\section{Study Area}

The Suwannee River basin is Florida's largest river basin. It is located in northcentral Florida, extends into Georgia (Figure 2) and is approximately $28,000 \mathrm{~km}^{2}$. The basin consists primarily of wetlands, forests, and farmlands (Ham and Hatzell, 1996). The Suwannee River Basin has subtropical climate (Crane, 1986). Average rainfall is $\sim 132 \mathrm{~cm} \mathrm{y}^{-1}$ and evapotranspiration rates are between 90 and $105 \mathrm{~cm} \mathrm{y}^{-1}$, but large annual variations in both are common (Crane, 1986).

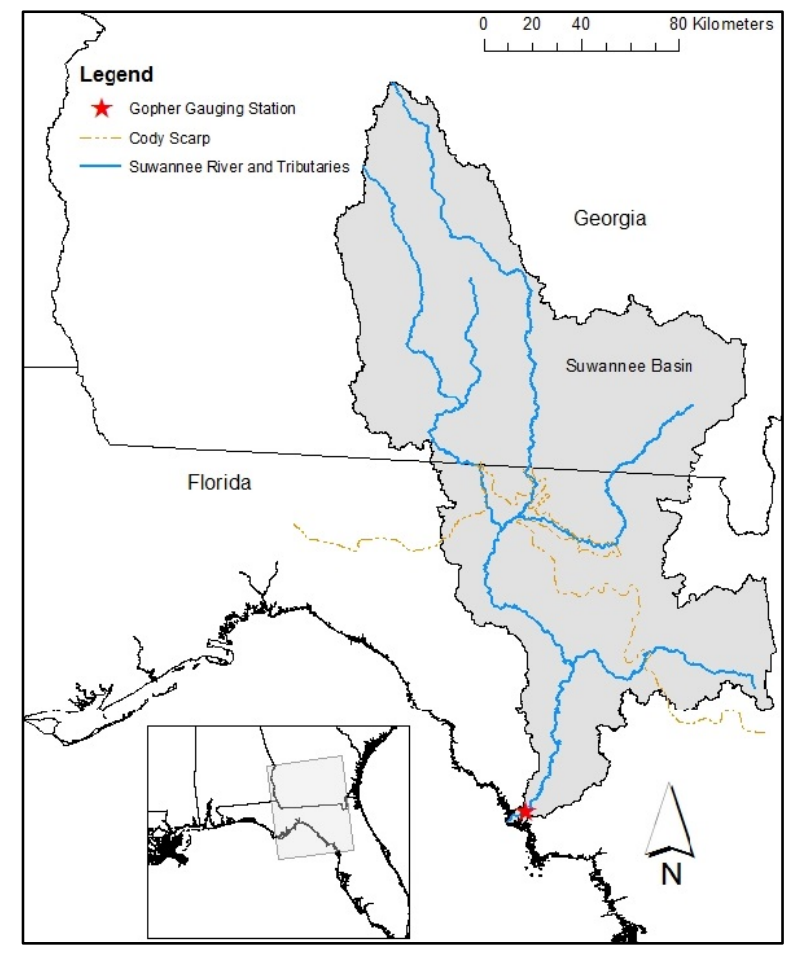

Figure 2: Map of the Suwannee River Basin, including the Gopher Gaging Station. Created using ArcMap.

In the upper 70\% of the Suwannee River Basin, the Hawthorn group, Miocene in age, is exposed at the surface. The Hawthorn group is composed of fine to coarse sands, 
silts, and clay materials. The Hawthorne group overlies the Ocala Limestone and acts a confining unit for the upper Floridian aquifer. In the lower $30 \%$ of the basin, the Hawthorn group has been removed by erosion and the Suwannee and Ocala limestones are exposed at the surface. Ocala is a fossiliferous limestone interbedded with dolostone and is Eocene in age, whereas the Suwannee Limestone a vuggy, muddy limestone that dates to the Oligocene (Scott et al., 1991; Martin and Gordon, 2000). The erosional limit of the Hawthorn Group is the Cody Escarpment, a topographic break approximately 30m in relief (Martin and Gordon, 2000).

Dense networks of surface streams are present above the Cody Scarp. Many of these streams sink into the subsurface where the flow off the Cody Scarp into the Suwannee or Ocala Limestones. Below the Cody Scarp, there are only two main rivers, the Suwannee and its tributary the Santa Fe. Prior to the two rivers converging, the Suwannee River at Branford gaging station has an average discharge rate of $351 \mathrm{~m} \mathrm{~s}^{-1}$. Both rivers receive a substantial quantity of their inflow from 18 first magnitude springs, which have flow rates greater than $2831.6 \mathrm{~L} \mathrm{~s}^{-1}$, and 87 second magnitude springs, with flow rates between 2831.6 L s${ }^{-1}$ to $283 \mathrm{~L} \mathrm{~s}^{-1}$ (Hornsby and Ceryak 1998). These first and second magnitude springs bring groundwater and dissolved limestone, to the surface. All rain falling in the Suwannee River Basin that is not lost to evapotranspiration is discharged via the Suwannee River to the Gulf of Mexico. There are no known submarine springs that discharge water from the Suwannee River Basin. This study focusses on calcium concentration data collected between July 1999 to August 2008 and specific conductivity data collected from October 2005 to September 2007. These time 
frames were selected based on the longest amount of continuous, approved data provided by the USGS.

\section{Methods}

\subsection{Water Flux from the Suwannee River Basin}

The Gopher River gaging station (USGS 02323592) is located 12 km from the terminus of the Suwannee River. Consequently, all water exiting the basin is measured at this station. Daily average discharge data were obtained from the USGS waterwatch online database (waterwatch.usgs.gov)

Discharge in the Suwannee River at the Gopher River gaging station is tidally influenced. During droughts, very high tides and anomalous barometric events, such as hurricanes, can cause discharge values to be negative. Only two days in our period of record were associated with negative daily average discharge values and both were treated as zero values.

\section{2 $\mathrm{Ca}^{2+}$ Flux from the Suwannee River Basin}

Karstification was quantified karstification by calculating the mass flux of calcite from the basin using three complementary approaches. In each case, the mass flux of calcite was determined on the basis of empirically derived relationships between dissolved $\mathrm{Ca}^{2+}$ concentrations measured in water samples that are collected at monthly intervals and discharge or specific conductance. Similar to Opdyke et al. (1984) and Willet (2006), it was assumed that all dissolved $\mathrm{Ca}^{2+}$ is derived from calcite dissolution and $1 \mathrm{~mol}$ of $\mathrm{Ca}^{2+}$ in solution is equivalent to $1 \mathrm{~mol}$ of $\mathrm{CaCO}_{3}$ being exported from the basin. 


\section{3 $\mathrm{Ca}^{2+}$ Flux from Concentration-Discharge Relationships}

Between July 1999, and August 2008 water samples were collected at monthly intervals and analyzed for major ions. Discharge ranges from $3.5 \times 10^{6}$ to $7.7 \times 10^{7} \mathrm{~m}^{3} \mathrm{~d}^{-}$

1. Data are available from the Suwannee River Water Management District data portal (mysuwanneeriver.com). Because daily discharge values are available for the entire period of record used in this work, the primary method of calculating $\mathrm{Ca}^{2+}$ flux relied on statistical relationships between $\mathrm{Ca}^{2+}$ and daily average discharge on the day of water sample collection, which was best described with a power law (Figure 3). Using the Generalized Reduced Gradient in the Solver Analysis with Microsoft Excel, four outliers (representing less than $4 \%$ of the data) were removed, improving the coefficient of determination from 0.4086 to 0.5052 . The power law relationship was used to calculate $\mathrm{Ca}^{2+}$ concentrations, ranging from $5.5 \times 10^{6}$ to $4.5 \times 10^{7} \mathrm{~mol} \mathrm{~d}^{-1}$, of water flowing through the Gopher River gaging station from daily discharge measurements and calculated daily $\mathrm{Ca}^{2+}$ flux from the basin by multiplying daily $\mathrm{Ca}^{2+}$ concentrations by daily discharge totals. We assessed error by comparing the modeled $\mathrm{Ca}^{2+}$ concentrations to the measured concentrations on days where measured concentrations were available. 


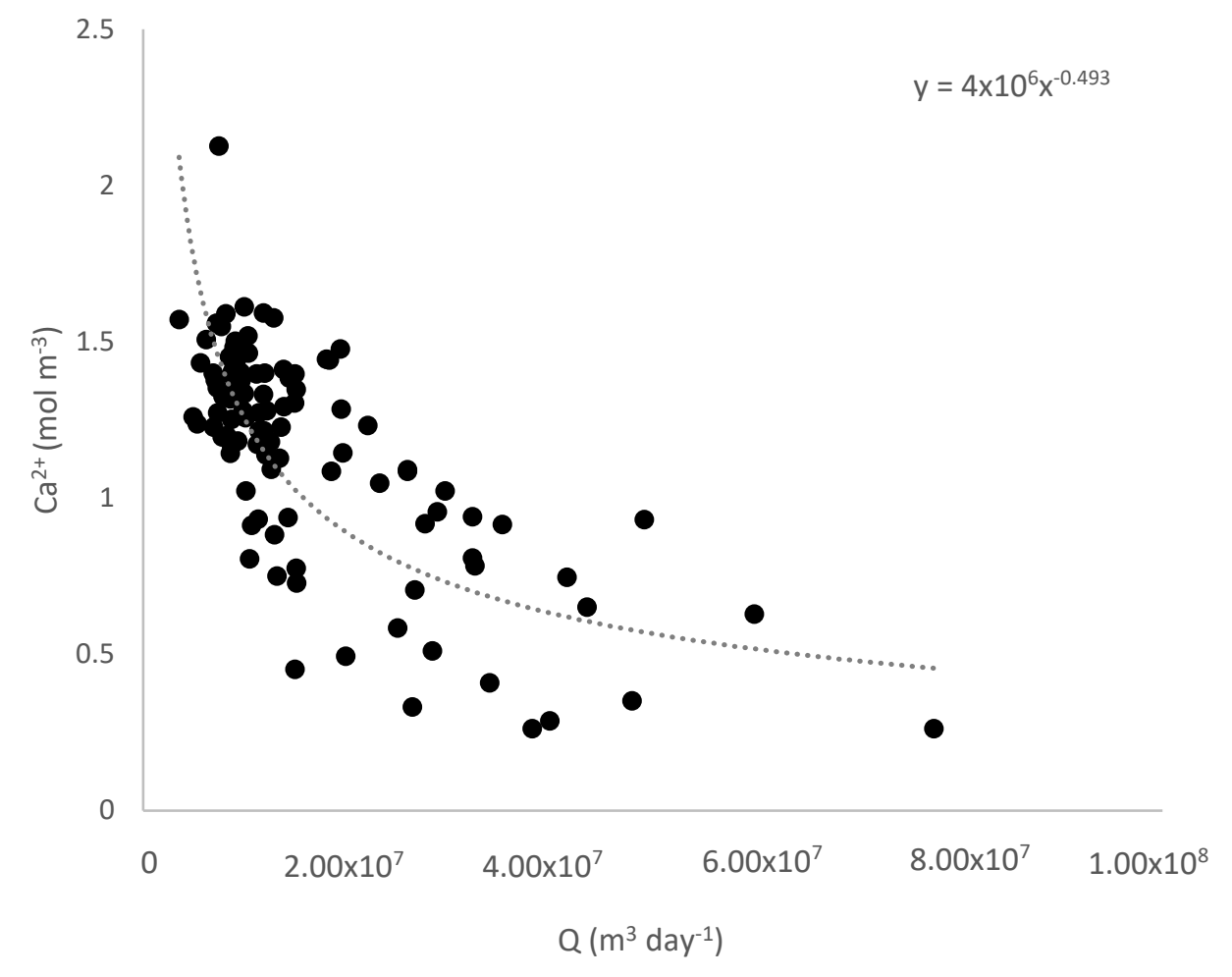

Figure 3: Ratings curve of $\mathrm{Ca}^{2+}$ compared to discharge (Q). $\mathrm{Ca}^{2+}$ decreases exponentially as a result of an increase in discharge at the Gopher River Station.

\section{4 $\mathrm{Ca}^{2+}$ Flux from Concentration-Conductivity Relationships}

The Gopher River gaging station continuously measured SpC and reported it as daily averages between 2005 to 2007 (data from USGS waterwatch online database). Because $\mathrm{Ca}^{2+}$ is the dominant cation in solution in limestone terrains, variation in $\mathrm{SpC}$ primarily reflects variation in $\mathrm{Ca}^{2+}$ concentration (Ford and Williams, 2007). The relationship between $\mathrm{SpC}$ and $\mathrm{Ca}^{2+}$ concentration in monthly water samples was fitted linearly (Figure 4). A least squares test resulted in the removal of two outliers (less than $6 \%$ of the data) improving the goodness of fit from 0.5375 to 0.9324 . We used a linear relationship to calculate $\mathrm{Ca}^{2+}$ concentrations from daily average $\mathrm{SpC}$ and calculated daily 
$\mathrm{Ca}^{2+}$ flux from the basin by multiplying daily $\mathrm{Ca}^{2+}$ concentrations by daily discharge totals. We assessed error by comparing the modeled $\mathrm{Ca}^{2+}$ concentrations to the measured concentrations on days where measured concentrations were available.

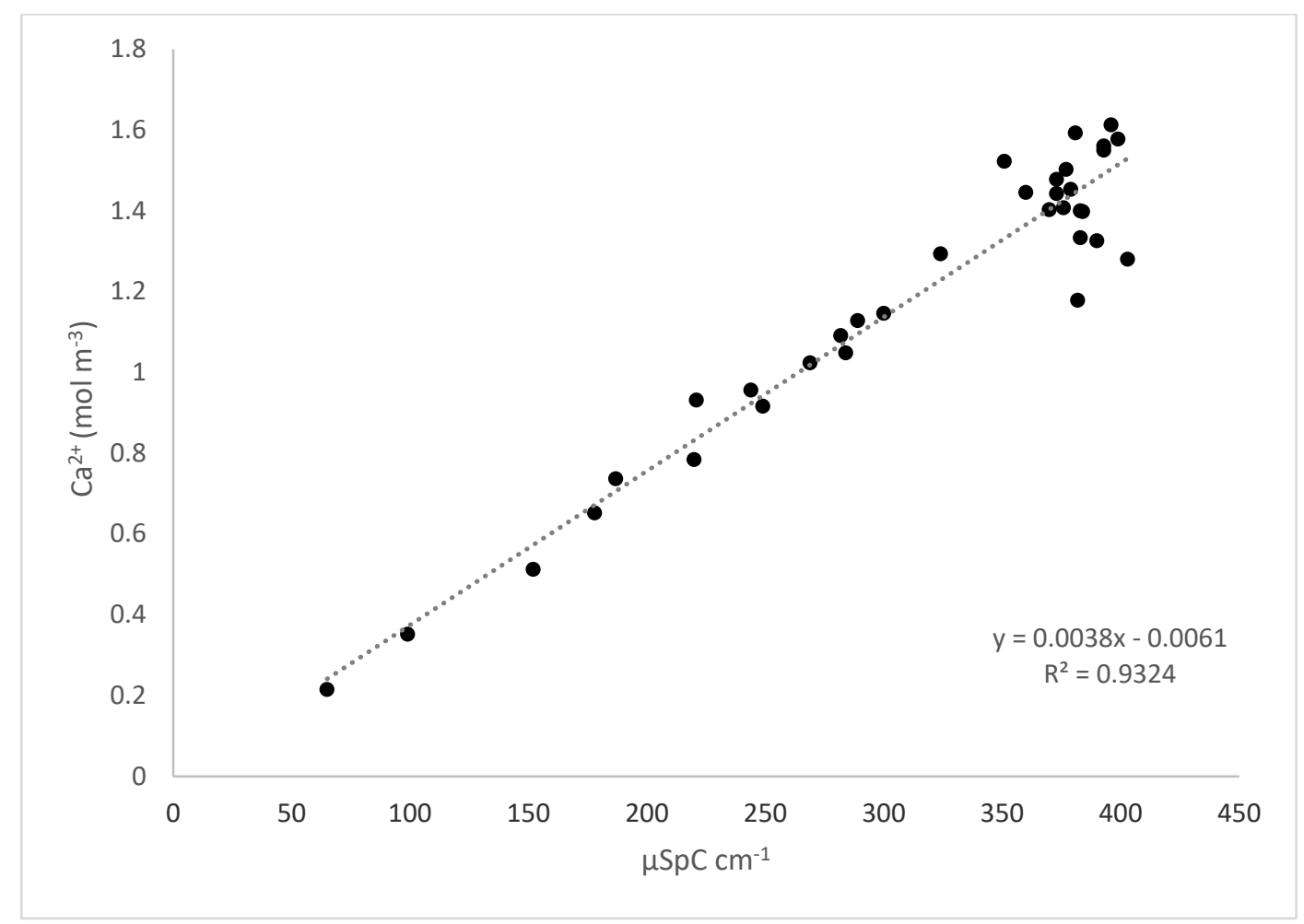

Figure 4: Ratings curve of specific conductivity $(\mathrm{SpC})$ and $\mathrm{Ca}^{2+}$. A positive linear relationship existed between $\mathrm{SpC}$ and $\mathrm{Ca}^{2+}$ with respect to discharge.

\subsection{Chemostatic $\mathrm{Ca}^{2+}$ Flux}

At low discharges, $\mathrm{Ca}^{2+}$ concentrations in the Suwannee River Basin remain constant with minor fluctuations in discharge (Gulley et al., 2013), indicating chemostatic conditions (Godsey et al., 2009). At higher discharges, $\mathrm{Ca}^{2+}$ concentrations decrease with discharge, indicating dilution. Because dilution indicates rainwater has not reacted to equilibrium with calcite bedrock, we decided to determine what the flux of $\mathrm{Ca}^{2+}$ would be 
if dilution effects were removed and all effective rainfall reacted to equilibrium with calcite. By extending the chemostatic relationship between $\mathrm{Ca}^{2+}$ and $\mathrm{Q}$ at low discharges to the entire range of discharges, we were able to assess how much limestone would have likely been removed if all effective rainfall infiltrated the aquifer and participated in karstification. $\mathrm{Ca}^{2+}$ fluxes were therefore calculated by multiplying the average $\mathrm{Ca}^{2+}$ concentration at the terminus of the Suwannee River during chemostatic conditions, which we defined as any discharge lower than $300 \mathrm{~m}^{3} \mathrm{~s}^{-1}$ (as determined in Gulley et al., 2013) by the total discharge. Physically, this approach would be the equivalent of removing the impermeable confining layer from the entire Suwannee River Basin. From a modeling standpoint, we consider the chemostatic scenario to represent the maximum amount of karstification that we would expect to occur in the Florida carbonate platform.

\subsection{Karstification}

Similar to the Opdyke and Willet studies, we calculate karstification assuming $\mathrm{Ca}^{2+}$ in solution was derived only from dissolution of the Ocala Limestone. We calculated the volume of calcite dissolved from the basin over each measurement interval by summing the total $\mathrm{Ca}^{2+}$ flux from the basin using the three methods described above. We converted the molar flux to volume of calcite dissolved by assuming a molar volume for calcite of $36.934 \mathrm{~cm}^{3} \mathrm{~mol}^{-1}$ (Robie et al., 1984) and we assumed a porosity of $30 \%$ to calculate the volume of Ocala limestone dissolved (Budd and Vacher, 2004). We express karstification as the volume of Ocala limestone dissolved by normalizing it to the area of the Suwannee River Basin, calculated from ArcMap. 


\subsection{Uplift}

Similar to the Opdyke and Adams studies, we calculated uplift resulting from karstification over a 1.6 million year time period using equation 1. Uplift rates were calculated based on karstification rates obtained using the $\mathrm{Ca}^{2+}-\mathrm{Q}, \mathrm{SpC}-\mathrm{Ca}^{2+}$ and chemostatic relationships. We assumed that these karstification rates were representative of the last 1.6 million years, that all dissolution occurred in the subsurface and that surface denudation was insignificant in comparison to subsurface karstification. In actuality, karstification and uplift rates would be lower than modern during periods of lower sea levels and their associated drier climates.

\subsection{Rainfall and Evapotranspiration}

While rainfall data does not factor into our calculation of karstification, we assess relationships between rain falling on the Suwannee River Basin and the volume of water leaving the basin as discharge to determine how reasonable rainfall might be as a dissolution indicator. We assume the difference between rainfall and discharge is approximately equal to evapotranspiration over annual timescales (Kirchner, 2009). Because rainfall that evaporates or transpires to the atmosphere does not export $\mathrm{Ca}^{2+}$ from the basin, rainfall may not be an ideal proxy for dissolution.

Rainfall data was collected from 12 USGS rain gauge stations located inside and adjacent to the basin. A majority of the rain gauging stations had 4 to 14 years of available daily rainfall data, with $75 \%$ of the stations having a decade or more of data. The volume of rain falling in the basin was calculated using Thiessen Method via ArcGIS 10.2.2. Polygons were adjusted through time, so that the number of polygons increased 
each time a new rain gage came on line. Precipitation was averaged over a two year period from 2005 to 2007. The period was selected based on having 10 operational rain stations, the most out of all the years, allowing for the greatest distribution of available data collection points over the basin.

\section{Results}

\subsection{Rainfall and Evapotranspiration}

Annual rainfall totals between 2001 and 2008 ranged from a high of $1.46 \mathrm{~m} \mathrm{y}^{-1}$ in 2004 to a low of $0.95 \mathrm{~m} \mathrm{y}^{-1}$ in 2007, with an average annual of $1.21 \mathrm{~m}$ (Figure 5).

Average annual discharge from the Suwannee River Basin, normalized to drainage basin area, ranged from $0.61 \mathrm{~m} \mathrm{y}^{-1}$ in 2005 to $0.12 \mathrm{~m} \mathrm{y}^{-1}$ in 2002, resulting in an annual average discharge, and hence effective rainfall, of $0.26 \mathrm{~m} \mathrm{y}^{-1}$ from 2001 to 2008. Evapotranspiration was determined to be $0.94 \mathrm{~m} \mathrm{y}^{-1}$ or $78 \%$ of the annual rainfall. Maximum evaporation was $1.19 \mathrm{~m} \mathrm{yr}^{-1}$ in 2004 and was at a minimum in in 2005 with $0.64 \mathrm{~m} \mathrm{y}^{-1}$. 


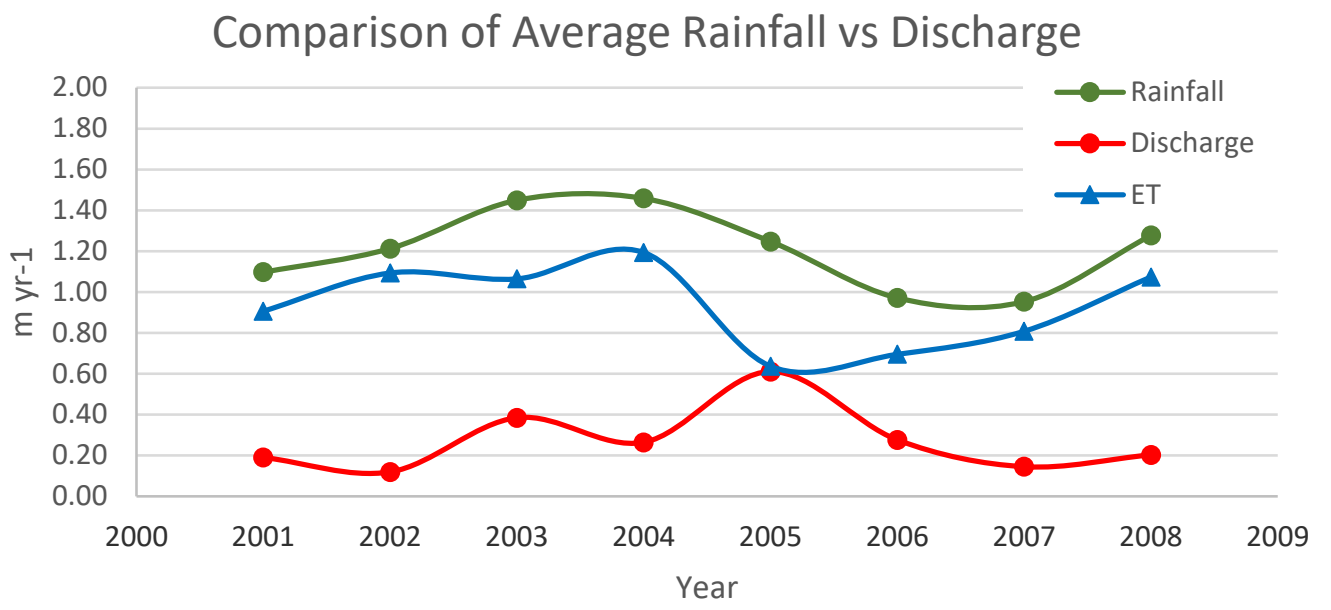

Figure 5: Comparison of annual rainfall, discharge at the Gopher River Station, and evapotranspiration over the Suwannee River Basin from 2001 to 2008.

\section{2 $\mathrm{Ca}^{2+}$ Fluxes}

Modeled daily fluxes of $\mathrm{Ca}^{2+}$ calculated from $\mathrm{Ca}^{2+}-\mathrm{Q}$ relationships varied from $\sim 3.14 \times 10^{6}$ to $4.27 \times 10^{7} \mathrm{~mol} \mathrm{~d}^{-1}$ (Figure $6 \mathrm{~B}$ ). Modeled $\mathrm{Ca}^{2+}$ concentrations were similar to measured $\mathrm{Ca}^{2+}$ concentrations during at low flows estimated at $2 \times 10^{7} \mathrm{~m}^{3} \mathrm{~d}^{-1}$ (Figure 3) but varied with increased discharge. Over the entire period of record, average residual values were 0.92 . Annual modeled $\mathrm{Ca}^{2+}$ flux varied from a low of $4.71 \times 10^{9} \mathrm{~mol} \mathrm{y}^{-1}$ in 2002 to a high of $8.74 \times 10^{9} \mathrm{~mol} \mathrm{y}^{-1}$ in 2005 and had a yearly average of $6.38 \times 10^{9} \mathrm{~mol}$ over the eight-year record (Table 2). 


\begin{tabular}{|c|c|c|c|}
\hline Year & $\mathrm{Ca}^{2+}-\mathrm{Q}$ & Chemostatic & $\mathrm{SpC}-\mathrm{Ca}^{2+}$ \\
\hline 2000 & $5.37 \times 10^{9}$ & $5.65 \times 10^{9}$ & \multirow{8}{*}{$6.29 \times 10^{9}$} \\
\hline 2001 & $5.33 \times 10^{9}$ & $5.98 \times 10^{9}$ & \\
\hline 2002 & $4.71 \times 10^{9}$ & $4.45 \times 10^{9}$ & \\
\hline 2003 & $8.40 \times 10^{9}$ & $1.44 \times 10^{10}$ & \\
\hline 2004 & $7.61 \times 10^{9}$ & $1.30 \times 10^{10}$ & \\
\hline 2005 & $8.74 \times 10^{9}$ & $1.59 \times 10^{10}$ & \\
\hline 2006 & $5.85 \times 10^{9}$ & $7.52 \times 10^{9}$ & \\
\hline 2007 & $5.01 \times 10^{9}$ & $5.00 \times 10^{9}$ & \\
\hline Average & $6.38 \times 10^{9}$ & $7.94 \times 10^{9}$ & $6.29 \times 10^{9}$ \\
\hline
\end{tabular}




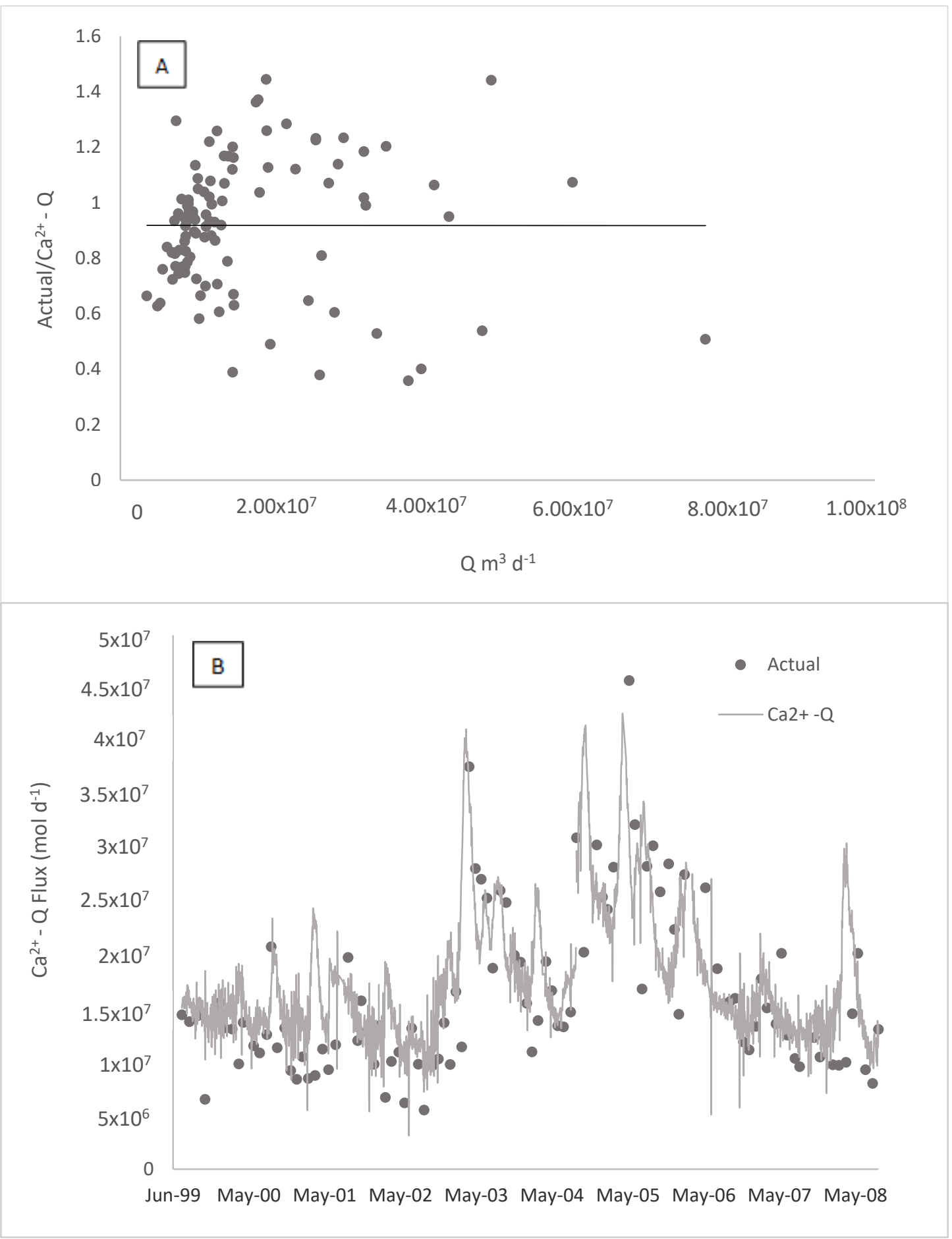

Figure 6: A) Residuals of actual flux measured at Gopher Station vs theoretical values calculated from the curve ratings. B) Time series of discharge with $\mathrm{Ca}^{2+}$ flux displayed as a line grey line while actual $\mathrm{Ca}^{2+}$ measurements are represented by black dots. 
Modeled daily fluxes of $\mathrm{Ca}^{2+}$ calculated from SpC-Ca ${ }^{2+}$ ranged from $2.47 \times 10^{6}$ to $4.14 \times 10^{7} \mathrm{~mol} \mathrm{~d}^{-1}$ (Figure 7B). Residual errors varied little between baseflow and periods of increased discharge, resulting in an average residual value of 1.01 over the entire period of record (Figure 7A). Annual $\mathrm{Ca}^{2+}$ flux can only be modeled for 2006, the only year in our dataset with a complete SpC timeseries is $6.29 \times 10^{9} \mathrm{~mol} \mathrm{y}^{-1}$. 

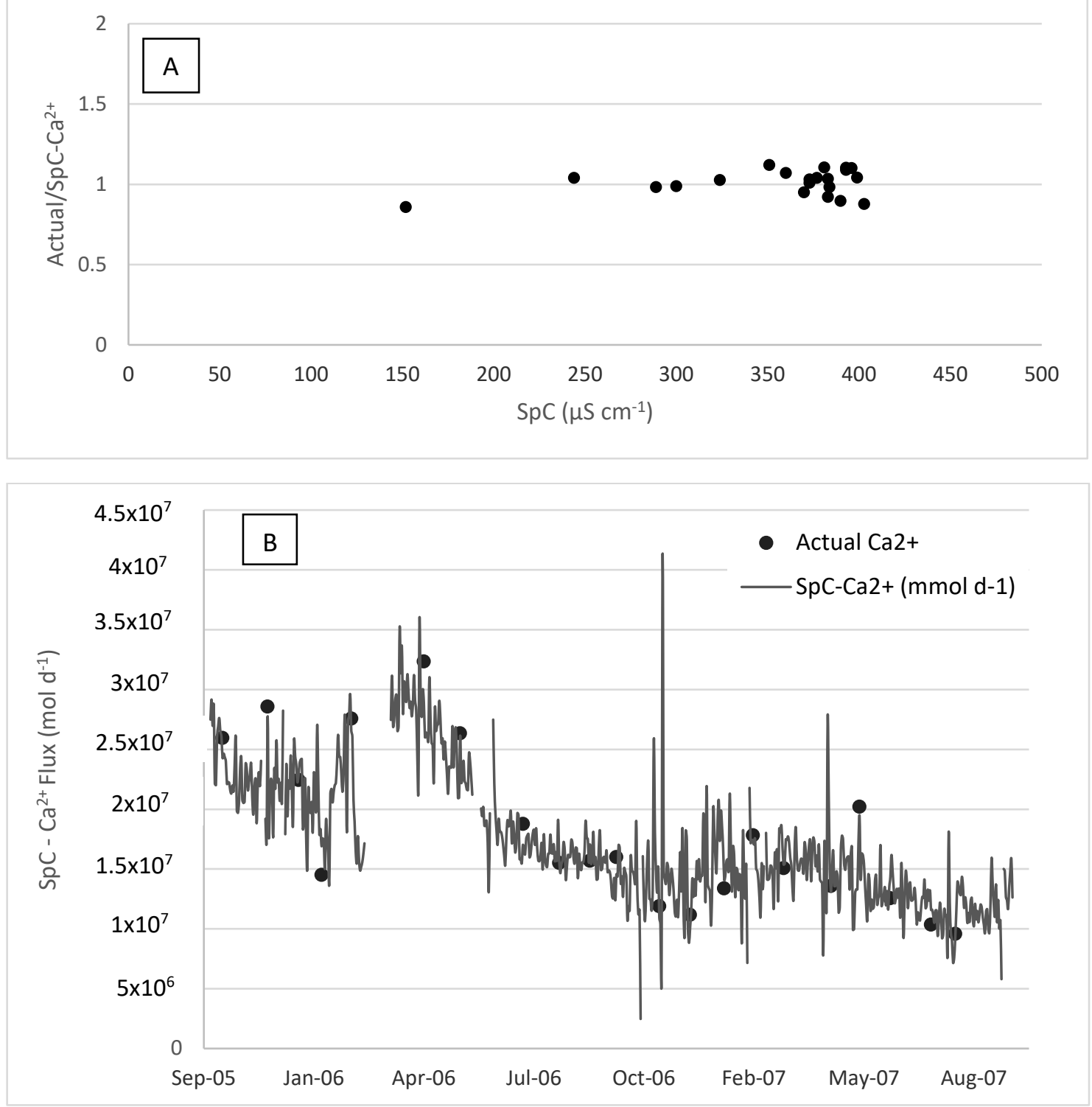

Figure 7: A) Residuals of actual flux measured at Gopher Station vs theoretical values calculated based on the linear relationship of $\mathrm{Ca}^{2+}$ to SpC. B) Time series of discharge with $\mathrm{Ca}^{2+}$ flux displayed as a line grey line while actual $\mathrm{Ca}^{2+}$ measurements are represented by black dots.

For the chemostatic model, fluxes of $\mathrm{Ca}^{2+}$ ranged from $\sim 7.19 \times 10^{5}$ to $1.23 \times 10^{8}$ mol d-1 (Figure 8). The lowest daily flux of $7.19 \times 10^{5} \mathrm{~mol} \mathrm{~d}^{-1}$ was in 2002, the driest year. The highest daily flux of $1.23 \times 10^{8} \mathrm{~mol} \mathrm{~d}^{-1}$ occurred in 2005 , the year with the 
highest rate of discharge from the basin. In 2005, the greatest annual loss of $\mathrm{Ca}^{2+}, 1.59 \mathrm{x}$ $10^{10} \mathrm{~mol}$ was recorded during that nine-year period.

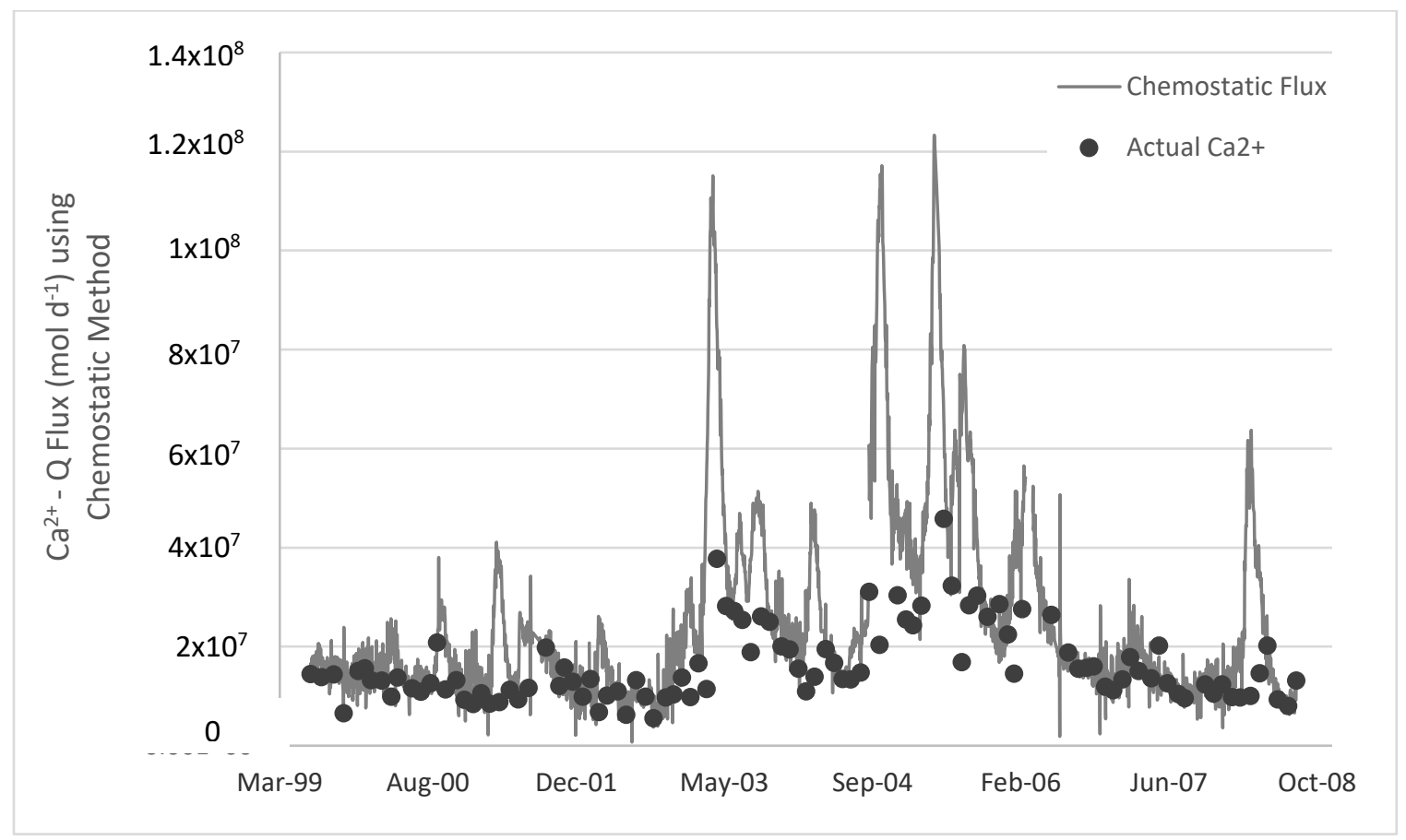

Figure 8. Time series of $\mathrm{Ca}^{2+}$-Q Flux at Gopher River Station, from July 1999 to October 2008, applying the chemostatic method. The black dots represent actual flux measured from the station while the grey line represents the predicted $\mathrm{Ca}^{2+}$ flux using the chemostatic method.

\subsection{Karstification}

Average karstification rates were highest when we assumed chemostatic conditions and lowest when we used the SpC-Ca ${ }^{2+}$ model. Our karstification rates varied within $30 \%$ of one another: SpC-Ca ${ }^{2+}$ had the lowest rate at $35.50 \mathrm{k} \cdot \mathrm{y} \cdot \mathrm{m}^{-1}, \mathrm{Ca}^{2+}-\mathrm{Q}$ at $34.48 \mathrm{k} \cdot \mathrm{y} . \mathrm{m}^{-1}$ and the chemostatic method having the highest rate at $24.90 \mathrm{k} \cdot \mathrm{y} . \mathrm{m}^{-1}$. In contrast, Opdyke et al. (1984) had slightly lower rates, at 41.45 k.y. m¹ ${ }^{-1}$, Willet’s (2006) method was the slowest of them all, 148.83 k.y. $\mathrm{m}^{-1}$ and Adams et al. (2010) had a 
significantly higher rate of karstification when compared to the other methods at 12.99 k.y. $\mathrm{m}^{-1}$ (Figure 9).

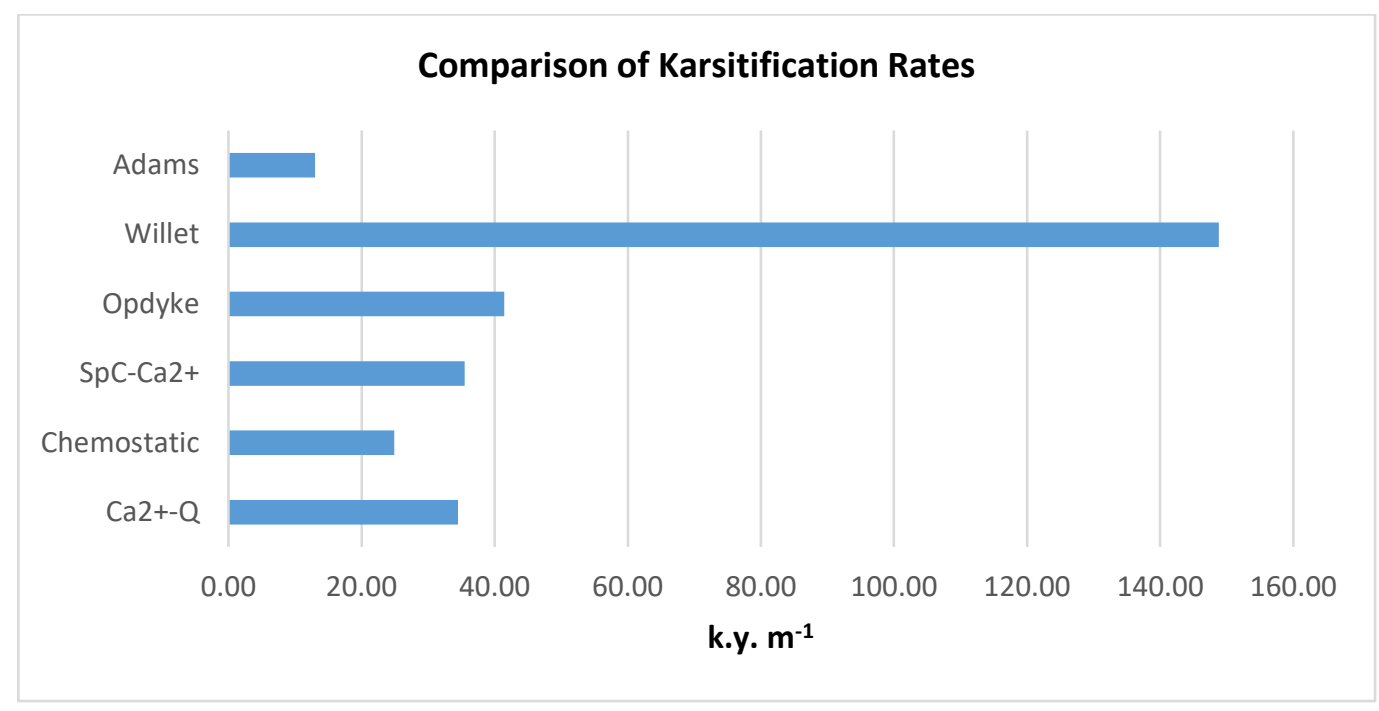

Figure 9: Comparison of karstification rates in thousands of years (k.y. $\mathrm{m}^{-1}$ ) using all methods described in this study.

\subsection{Uplift}

Average annual uplift rates reflect annual karstification rates. Uplift rates were highest for chemostatic conditions and lowest for SpC-Ca ${ }^{2+}$. The uplift rates varied within 30\% from the highest to the lowest rate: chemostatic with the highest rate at 40.2 $\mathrm{m} \mathrm{m} \cdot \mathrm{y}^{-1}, \mathrm{Ca}^{2+}-\mathrm{Q}$ at $29.0 \mathrm{~m}$ m.y. ${ }^{-1}$, and the SpC-Ca ${ }^{2+}$ method having the lowest uplift rate at $28.2 \mathrm{~m} \mathrm{m.y.}{ }^{-1}$. Opdyke et al. (1984) and Willet (2006) had significantly lower average annual uplift rates at $24.1 \mathrm{~m} \mathrm{m.y.}{ }^{-1}$ and $6.72 \mathrm{~m} \mathrm{m.y.}{ }^{-1}$, respectively. Adams et al. (2010) uplift rate was higher than the other methods, resulting in 77.0 m m.y. ${ }^{-1}$. 


\section{Discussion}

Our three models of karstification and uplift are similar in magnitude to the estimates of Opdyke et al. (1984), but significantly greater than Willet (2006) and significantly lower than Adams et al. (2010). In the following section, we examine the limitations of our karstification model and suggest reasons for differences between our models and those of Opdyke, Willet and Adams.

\subsection{Rainfall and Evapotranspiration}

The primary driving force for karstification is effective rainfall (i.e. recharge) which infiltrates into carbonate bedrock subsurface. Our results suggest that, on average, $78 \%$ of annual rainfall is returned to the atmosphere via evapotranspiration. Because the Adams at al. (2010) model relates karstification to rainfall, rather than recharge, it may overestimate dissolution rates because water that leaves the basin through evapotranspiration does not export carbonate bedrock from the basin.

\subsection{Comparison of $\mathrm{Ca}^{2+}-\mathrm{Q}$ and SpC-Ca ${ }^{2+}$ Models}

While the statistical relationships between $\mathrm{Ca}^{2+}-\mathrm{Q}$ and $\mathrm{SpC}-\mathrm{Ca}^{2+}$ were significantly different, the overall magnitude of karstification estimated by the two models differed by only 3\%. The poor correlation between $\mathrm{Ca}^{2+}-\mathrm{Q}$ is likely caused by hysteresis in the relationships between $\mathrm{Ca}^{2+}$ and Q (Gulley et al., 2011). $\mathrm{Ca}^{2+}$ concentrations in the Suwannee River basin are lower on the rising limb of the hydrograph, when rapid increases in river stage hydraulically dam inputs of $\mathrm{Ca}^{2+}$ rich groundwater from karst springs; $\mathrm{Ca}^{2+}$ concentrations are higher for equivalent discharges on the falling limb of flood hydrographs because $\mathrm{Ca}^{2+}$-rich groundwater begins flowing 
back into the river (Gulley et al., Dec 2013). Consequently, statistical relationships between $\mathrm{Q}$ and $\mathrm{Ca}^{2+}$ are weak. In contrast, $\mathrm{SpC}$ is a direct function of the number of ions in solution. Because $\mathrm{Ca}^{2+}$ is the dominate cation, statistical correlations between $\mathrm{Ca}^{2+}$ and $\mathrm{SpC}$ are strong and $\mathrm{Ca}^{2+}$ concentrations can be calculated from $\mathrm{SpC}$ records with reasonable accuracy during the rising and falling limb of individual flood events. The similarity in annual karstification rates calculated the $\mathrm{SpC}-\mathrm{Ca}^{2+}$ and $\mathrm{Ca}^{2+}-\mathrm{Q}$ models suggests that, while $\mathrm{Ca}^{2+}$-Q relations do not describe instantaneous fluxes of $\mathrm{Ca}^{2+}$ particularly well, the residual errors cancel out and allow annual $\mathrm{Ca}^{2+}$ fluxes to be approximated with the same degree of accuracy as the SpC-Ca ${ }^{2+}$ model.

\subsection{Chemostatic Model}

Maximum theoretical karstification rates were calculated for the basin by assuming chemostatic conditions. Chemostatic conditions assume that all rainfall is able to infiltrate into the ground and equilibrate with carbonate minerals. While many of Florida’s springs and spring fed rivers are essentially chemostatic, the Suwannee River Basin, like many of Florida's river basins, is not. Typically, the Suwannee River is chemostatic until discharge exceeds $300 \mathrm{~m} \mathrm{~s}^{-1}$. Discharge that exceeds this threshold is derived from runoff from the upper $70 \%$ of the Suwannee River basin, which is overlain by low-permeability siliciclastics that generate runoff that has not reacted to equilibrium with carbonate minerals. During floods, the hydraulic head in the river becomes greater than the hydraulic head in surrounding groundwater, hydraulically damming groundwater inputs to the river and allowing the majority of floodwater to discharge to the Gulf of Mexico without reacting to equilibrium with carbonate minerals (Gulley et al., Dec 
2013). Differences between our $\mathrm{Ca}^{2+}-\mathrm{Q}$ and $\mathrm{SpC}-\mathrm{Ca}^{2+}$ models with the chemostatic model suggest that if all runoff from the Suwannee River Basin were to react to equilibrium with calcite, average annual karstification rates would be $27-29 \%$ greater than predicted by our $\mathrm{Ca}^{2+}$-Q and $\mathrm{SpC}-\mathrm{Ca}^{2+}$ models. We thus consider the chemostatic model to be a theoretical maximum for karstification within the basin.

\subsection{New Constraints on Karstification and Uplift}

Our results provide new constraints on karstification and uplift rates for Florida. The Suwannee River Basin has well-documented hydrological boundaries, providing previously unavailable constraints on the footprint of karstification, and our statistical models allow $\mathrm{Ca}^{2+}$ flux to be estimated for the entire Suwannee River Basin at daily timescales. Willet (2006) and Opdyke et al. (1984) studies used coarse resolution sampling of karst springs, which do not account for temporal variability in carbonate fluxes and have only limited information to constrain drainage basin area. Groundwater flow patterns and unrecorded springs may alter the magnitude of $\mathrm{Ca}^{2+}$ removal from investigations not utilizing a delineated basin.

\subsection{Comparison of Opdyke, Willet, and Adams Studies}

Two of our long-term karstification models, $\mathrm{Ca}^{2+}-\mathrm{Q}$ and $\mathrm{SpC}-\mathrm{Ca}^{2+}$, are similar in magnitude to Opdyke's et al. (1984) estimates. Since our models our within 3\% of each other, we will compare the karstification rate of $\mathrm{Ca}^{2+}$-Q, which had the slightly faster rate. Opdyke's et al. (1984) karstification rate was $17 \%$ lower than $\mathrm{Ca}^{2+}-\mathrm{Q}$. Willet's (2006) model used a similar approach but factored in a more robust dataset, which included a number of second and third magnitude springs collected in the early 2000s via 
Scott et al. (2004), resulting in the use of over 400 springs for the study. Willet's (2006) had a karstification rate 77\% lower than $\mathrm{Ca}^{2+}-\mathrm{Q}$ and $72 \%$ lower than Opdyke's et al. (1984) calculation. Willet (2006) determined the difference for his lower rate was Opdyke et al. (1984) assumed higher values for carbonate lost through spring discharge. Willet (2006) argued he had a more robust dataset of spring discharge; however, the difference could be a result of flux per unit area. The study area Opdyke et al. (1984) used was the north central part of the Florida peninsula accounting for only $30 \%$ of the state. In contrast, Willet (2006) expanded his study area to cover as estimated $50 \%$ by including the Florida panhandle. When comparing the volume of water estimated to have discharged from the springs, Willet (2006) calculation of $2.29 \times 10^{7} \mathrm{~m}^{3} \mathrm{~d}^{-1}$ was only $18 \%$ greater than Opdyke’s et al. (1984). Willet’s (2006) expanded study area showed a decrease in flux per unit area when compared to Opdyke's et al. (1984), resulting in a decreased karstification rate of the carbonate matrix.

Our statistical models of karstification suggest that the numerical model used by Adams et al. (2010) significantly overestimate karstification. Karstification rates predicted by the Adams model are $62 \%$ greater than the $\mathrm{Ca}^{2+}$-Q model and $48 \%$ greater than the chemostatic model. The inability of the chemostatic model to match the karstification rates of Adams et al. (2010) suggest that relating dissolution rates to rainfall, rather than recharge, would overestimate dissolution rates even if all effective rainfall was retained on, or within, the Florida carbonate platform until it equilibrated with carbonate bedrock. 


\subsection{Comparison of Uplift Calculations}

While our results suggest that karstification can account for much of the uplift required to get the beach ridges to their present elevation, the models make a number of assumptions that may result in overestimation of uplift. Our models assume current climate conditions reflect past climate and do not account for known climate variability over the Plio-Pliestocene. We know that Florida had a much drier climate during glacial periods, suggesting that our karstification rates are too high. Decreased rainfall, particularly between 800 k.y. to 400 k.y., as suggested by Adams et al. (2010) from his model, would decrease the karstification rate, significantly so that the decrease in evapotranspiration rates would not be able to offset the loss of infiltrated water into the carbonate bedrock.

Because uplift rates are a direct function of karstification, discrepancies between uplift rates reflect discrepancies with karstification rates. Our $\mathrm{Ca}^{2+}-\mathrm{Q}, \mathrm{SpC}-\mathrm{Ca}^{2+}$, and chemostatic models produced uplift rates of $46.1 \mathrm{~m}, 45.1 \mathrm{~m}$, and $54.4 \mathrm{~m}$, respectively, within 1.6 m.y. Our uplift rates are therefore similar to, but slightly faster than Opdyke’s et al. (1984) model which predicts $38.4 \mathrm{~m}$ of uplift during that same time period. In contrast, 6.82 m.y. are required for Willet's (2006) model to achieve $50 \mathrm{~m}$ of uplift but only 0.59 m.y. for Adams et al. (2010).

\subsection{Unresolved Questions}

Our models, along with Opdyke’s et al. (1984) model, only provide 30-40 m of uplift of the $50 \mathrm{~m}$ beach terraces. Additional mechanism would be needed in order to 
account for the difference in height. One explanation was offered by Walcott (1972), describing farfield glacial isostatic adjustments along the east coast of the United States. Walcott (1972), suggests the removal of the Laurentide Ice Sheets of ice caused an isostatic rebound throughout much of the east coast, including Florida, which could account for the additional uplift needed. Indeed, the warped coastline indicates uplift is not driven by steady rate processes, but of varying karstification rates driven by precipitation and glacial isostatic rebound.

A second factor not accounted for was denudation of the surface over the period of study. Any mass lost over the surface would lower the resulting uplift. Willet (2006) and Opdyke et al. (1984) used an estimate of 10m of denudation. The extent to which the area experienced denudation is unknown.

\section{Conclusion}

The models presented in this study were used explain a significant portion of uplift observed in terraces in northern Florida. Previous models assumed calcium measurements taken from first and second magnitude springs across the region and did not account for yearly fluctuations in discharge. Other studies using precipitation as the driver for dissolution neglect evapotranspiration rates; therefore, not being able to predict fluxes of calcium into the oceans through discharge. Compared to previous work, our models encompass a defined study area based on the Suwannee River watershed, with discharge measurements taken from the pour point of a system.

The dissolution rates for our models were slightly faster than that determined by Opdyke’s et al. (1984) model. However, since our models were derived under current 
climate conditions, not necessarily reflecting that of intermittent glacial periods, we conclude that the Opdyke et al. (1984) model would be more suitable of that time period than the Adams et al. (2010).

\section{Work Cited}

Adams, P. N., Opdyke, N. D., \& Jaeger, J. M. (2010). Isostatic uplift driven by karstification and sea-level oscillation: Modeling landscape evolution in north Florida. Geology, 38(6), 531-534.

Anderson, R. S., \& Anderson, S. P. (2010). Geomorphology: the mechanics and chemistry of landscapes. Cambridge University Press.

Budd, D. A., \& Vacher, H. L. (2004). Matrix permeability of the confined Floridan Aquifer, Florida, USA. Hydrogeology Journal, 12(5), 531-549.

Champagnac, J. D., Molnar, P., Anderson, R. S., Sue, C., \& Delacou, B. (2007). Quaternary erosion-induced isostatic rebound in the western Alps. Geology, 35(3), 195-198.

Crane, J. J. (1986). An investigation of the geology, hydrogeology, and hydrochemistry of the Lower Suwannee River Basin. State of Florida, Department of Natural Resources, Division of Resource Management, Bureau of Geology, published for the Florida Geological Survey.

Farrand, W. R. (1962). Postglacial uplift in North America. American Journal of Science, 260(3), 181-199.

Ford, D., \& Williams, P. D. (2007). Karst hydrogeology and geomorphology. John Wiley \& Sons.

Gulley, J., Martin, J. B., Screaton, E. J., \& Moore, P. J. (2011). River reversals into karst springs: A model for cave enlargement in eogenetic karst aquifers. GSA Bulletin, 123(3-4), 457-467.

Gulley, J., Martin, J., Spellman, P., Moore, P., \& Screaton, E. (2013). Dissolution in a variably confined carbonate platform: effects of allogenic runoff, hydraulic damming of groundwater inputs, and surface-groundwater exchange at the basin scale. Earth Surface Processes and Landforms, 38(14), 1700-1713.

Godsey, S. E., Kirchner, J. W., \& Clow, D. W. (2009). Concentration-discharge relationships reflect chemostatic characteristics of US catchments. Hydrological Processes, 23(13), 1844-1864.

Ham, L. K., \& Hatzell, H. H. (1996). Analysis of nutrients in the surface waters of the GeorgiaFlorida coastal plain study unit, 1970-91. Water-resources investigations report (USA).

Hornsby, H. D., \& Ceryak, R. (1998). Springs of the Suwannee River basin in Florida. Department of Water Resources, Suwannee River Water Management District.

Kirchner, J. W. (2009). Catchments as simple dynamical systems: Catchment characterization, rainfall-runoff modeling, and doing hydrology backward. Water Resources Research, 45(2). 
Lucchitta, I. (1979). Late Cenozoic uplift of the southwestern Colorado Plateau and adjacent lower Colorado River region. Tectonophysics, 61(1), 63-95.

Martin, J. B., \& Gordon, S. L. (2000). Surface and ground water mixing, flow paths, and temporal variations in chemical compositions of karst springs. Groundwater flow and contaminant transport in carbonate aquifers. AA Balkema, 65-92.

Miller, K. G., Kominz, M. A., Browning, J. V., Wright, J. D., Mountain, G. S., Katz, M. E., ... \& Pekar, S. F. (2005). The Phanerozoic record of global sea-level change. Science, 310(5752), 1293-1298

Officer, C. B., \& Drake, C. L. (1982). Epeirogenic plate movements. The Journal of Geology, v. 90. 139-153.

Opdyke, N. D., Spangler, D. P., Smith, D. L., Jones, D. S., \& Lindquist, R. C. (1984). Origin of the epeirogenic uplift of Pliocene-Pleistocene beach ridges in Florida and development of the Florida karst. Geology, 12(4), 226-228.

Pirkle, F. L., \& Czel, L. J. (1983). Marine fossils from region of Trail Ridge, a Georgia-Florida landform. Southeastern Geology, 24(1), 31-38.

Robie, R. A., Hemingway, B. S., \& Fisher, J. H. (1984). Thermodynamic Properties of Minerals and Related Substances at 298.15 K and 1 Bar (10-5 Pascals) Pressure and at Higher Temperatures. US Geological Survey.

Rosenau, J. C. and Faulkner, G. L., (1975). An index to springs: Florida Bureau of Geology. Map 63.

Rosenau, J. C., Faulkner, G. L., Hendry, C., \& Hull, R. W. (1977). Springs of Florida. Florida Bureau of Geology Bulletin, (31).

Scott, T. M., \& Lloyd, J. (1991). M, and Maddox, Gary, Florida's Groundwater Quality Monitoring Program: Hydrogeological Framework. Florida Geological Survey Special Publication, (32).

Scott, T. M., Means, G. H., Means, R. C., Meegan, R. P. (2002). First magnitude springs of Florida, Open file report No. 85. Tallahassee, FL: State of Florida Department of Environmental Protection, Divison of Resource Assessment and Management, Publish for the Florida Geological Survey, $138 \mathrm{p}$.

Scott, T. M., Means, G. H., Meegan, R. P., Means, R. C., Upchurch, S., Copeland, R. E., Jones, J., Roberts, T., and Willet, A. (2004). Springs of Florida., Bulletin No. 66. Tallahassee, FL: State of Florida Department of Environmental Protection, Division of Resource Assessment and Management, Published for Florida Geological Survey, 377 p.

Slack, L. J., and Rosenau, J. C., (1979) Water quality of Florida springs: Florida Bureau of Geology. Map 96.

Suwannee River Water Management District data portal Live Edit. (n.d.). Retrieved May 2, 2015, from http://www.srwmd.state.fl.us/ 
USGS WaterWatch -- Streamflow conditions. (n.d.). Retrieved May 2, 2015, from http://waterwatch.usgs.gov/

Walcott, R. I. (1972). Late Quaternary vertical movements in eastern North America:

Quantitative evidence of glacio-isostatic rebound. Reviews of Geophysics, 10(4), 849-884.

Willet, M.A., 2006. Effect of dissolution of the Florida carbonate platform on isostatic uplift and relative sea level change [M.S. thesis]: Tallahassee, Florida State University, 102 p.

Winker, C. D., \& Howard, J. D. (1977). Plio-Pleistocene paleogeography of the Florida Gulf Coast interpreted from relict shorelines: Gulf Coast Association of Geological Societies. Transactions, $27,409-420$. 